\title{
Effects of season calving and managements on lactating curves in two different farms (organic vs conventional) in buffalo cows
}

\author{
Fiorella Sarubbi, Franca Polimeno, Giuseppe Auriemma, Giuseppe Maglione, \\ Rodolfo Baculo, Raffaele Palomba
}

National Research Council, ISPAAM Institute, Naples, Italy; 'Corresponding Author: fiorella.sarubbi@cnr.it

Received 10 October 2012; revised 11 November 2012; accepted 17 November 2012

\begin{abstract}
A total of 5852 records concerning daily milk yield, content of protein and fat, and somatic cell count was recorded in two farms (organic and conventional). Somatic cell count was log10transformed before analysis because was not normally distributed. The mixed model methodology was used according to a repeated-measures scheme, as the restricted maximum likelihood method to estimate lactation curves at different season of calving and at different calving order. Calving order affected milk yield only in the first three calving order with the lowest production levels in the first six months of the year for both farm; no effect could be observed on fat and protein contents. The organic farm shows the minor milk production (7.77 vs 8.10 $\mathrm{kg} /$ day/head organic and traditional respectively), but good qualitative characteristics of milk, and minor content of Somatic Cell Count. The milk production is major, in traditional farm, in summer respect the winter (10.4 vs $6.34 \mathrm{~kg}$ of milk/dayl head). In biological farm no difference between seasons were observed. Peak milk yield occurs, for both farms, at around the $6^{\text {th }}-7^{\text {th }}$ wk of lactation.
\end{abstract}

Keywords: Buffalo; Organic and Traditional Farm; Milk Yield; Milk Constituent; Season Calving

\section{INTRODUCTION}

The feature of buffalo species is a great capacity to face adverse environmental conditions and a remarkable longevity: a buffalo cow can produce up to $10 \mathrm{yr}$ and more.

The increasing economic relevance of the Italian buffalo depend from absence of production quotas in the European Community and, above all, from high market demand of mozzarella cheese obtained by buffalo milk, which results in price more than double of cow milk.

Normally animal are kept on paddocks and feeding is mainly based on unifeed during lactation and on pasture for dry cows and young animal. The productive cycle is usually seasonal; most calving is concentrated in the period July to December, as autumn is the natural mating season. The Italian buffalo cow produces on overages $2150 \mathrm{~kg}$ of milk for lactation with $8.28 \%$ and $4.74 \%$ of fat and protein respectively [1]. However, in this species, there is limited knowledge of the effects of main factors affecting milk production. Actually, studies on dairy buffalo are few and discontinuous [2-4], probably due to the great differences in the environment and in the productive level of animals in the different countries. In particular, disentangling the effect of the stage of lactation from other factors - such as management type, parity, season of calving and season of production, is difficult.

Studies on dairy cattle have shown that the effect of lactation length accounts for a substantial amount of the variation in the production of milk and in its composition. The use of mathematical functions to model the evolution over time of milk production is able to separate the effect of the lactation stage from other environmental factors only when they average out over lactation [5]. To properly consider the factors whose impact can change over time, i.e., over several test-day (TD) measures within lactation [6]; the direct analysis of TD measures by mixed linear models has been proposed as an alternative to lactation curve fitting. In recent years, these approaches have been brought into one perspective in TD models that use mathematical functions as covariates to account for the lactation curve $[7,8]$. This methodology has proved to be particularly useful in situations in which large amounts of data are available and the effects of environmental factors have been extensively studied, as in the case with the genetic evaluation of dairy cattle.

Also, somatic cell count (S.C.C.) is other important parameter because an increase of S.C.C. corresponding 
often at an inflammation of the mammary gland and influence milk quality. [9] reported that S.C.C. has a negative effect on milk and lactose yield in buffaloes, causing the drop in milk production and milk quality. [10,11] have shown no change in fat content, but found a decrease in total fat yield because of a decline in milk production, moreover [10] have shown elevated S.C.C. is associated with a decrease in lactose because of reduced synthetic activity of the mammary tissue. [12,13] observed the positive correlation between total protein content and S.C.C. content. [13] reported that when the content S.C.C. increased the lactose content reduced.

The objective of this study was to check the effect of calving season and calving order on milk yield and its characteristics at two different managements.

\section{MATERIALS AND METHODS}

\subsection{The Herds}

This study was conducted at an organic and conventional farms located in the south Italy, both near Salerno. Its territory extends from east to west by the Tyrrhenian Sea to Mount Soprano (1082 m) and from north to south by the river Sele River Solofrone.

The landscape is characterized, from west to east, with a long coastline with wide sandy beaches also 80 meters, followed by a lush pinewood band then a vast plain, intensively cultivated, which comes on the slopes of the mountain range, covered in National Park of Cilento and Vallo di Diano, where there is the historic core of the village.

The average temperature of the coldest month, January, came in at $+6.8^{\circ} \mathrm{C}$, one of the hottest month, August, is $+24.4^{\circ} \mathrm{C}$.

The farms are located about 441 meters above sea level.

In the organic farms the breeding facilities are spacious, modern and comfortable.

The animals were fed a total mixed ration of $22 \mathrm{~kg}$ of dry matter/day/head consisting of (\% of dry matter): corn silage (37.5\%), concentrate (43.9\%), and barley straws (18.6\%) for traditional farm; in the organic farm, the animal received a diet, composed from 59\% of grass silage, $35 \%$ of wheat straw and from $6 \%$ of concentrate.

The chemical composition of the two unifeed was reported in Table 1.

The vanguard milking techniques guarantee impeccable hygiene, superior milk quality and well-being of the animals in fact the introduction of robots for the milking have changed the milking process itself: the buffaloes regained a more natural and less distressing rhythm of life, they can decide themselves when to give milk. The farmers on the other hand no longer need to subject themselves to the animals needs but assume the role of observers and supervisors.

The data for M.Y. were obtained from two mechanics milking (0500 and $1700 \mathrm{~h}$ ) for both farm.

All procedures used in the experiment were in accordance with the ethical procedure for animal welfare.

\subsection{Farms Investigations}

A total of 5852 records concerning daily milk yield (MY), percentages of fat $(\% \mathrm{~F})$, protein $(\% \mathrm{P})$ and somatic cell counts (S.C.C.) were collected and analyzed on 1534 Italian buffalo cows and were observed on two family farm located in Salerno-South-Italy (organic and conventional).

The organic farm has about 210 heads in lactation, with an average production of $1831 \mathrm{~kg}$ of milk, 8.95 and $4.61 \%$ of fat and proteins respectively, in 240 days of lactation. The traditional farm has about 471 heads in lactation, with an average production of $1855 \mathrm{~kg}$ of milk, $8.31 \%$ and $4.75 \%$ of fat and proteins respectively in 201 days of lactation.

The lactation length was fixed at $210 d$ and it was died into 10 intervals of $20 d$ each, starting from 10 day postpartum.

\subsection{Statistical}

Data were grouped according to the following factor: calving season (4 levels: 1 st = January to March; 2nd = April to June; 3rd = July to September; 4 th $=$ October to December), calving order (9 level: $1=1 ; 2=2 ; 3=3 ; 4$ $=4$ at $6 ; 5=7$ at $8 ; 6=9$ and beyond)

The milk constituents were analyzed from the mixer of both milking and analyzed by infrared method Milko scan 133B. S.C.C. was determined by fluoro optometric method (Fossomatic 90).

Somatic cell count was log10-transformed before analysis because the S.C.C. was not normally distributed.

ANOVA is carried out to evaluate eventually significative differences between farm on milk production and milk quality. The Pearson correlation was effectuated for valuating the relationship between parameter.

Table 1. Chemical composition of the two unified.

\begin{tabular}{|c|c|c|}
\hline & Unifeed Organic Farm & Unifeed Conventional Farm \\
\hline Crude Protein & 6.87 & 7.89 \\
\hline Crude Fiber & 20.0 & 64.55 \\
\hline NSC & 25.0 & 18.23 \\
\hline Milk Forage Units/kg Dry Mater & 0.80 & 0.88 \\
\hline
\end{tabular}


The mixed model methodology was used according to a repeated-measure scheme, as well as the restricted maximum likelihood method available in the software of [14].

In general the model can be presented was:

$$
y_{i j k l m}=\alpha+v_{i}+o_{j}+c_{1}+(o c)_{k l}+e_{i j k l m}
$$

where $y_{i j k l m l}=$ M.Y. or \%F, \%P and SCCt.; $\alpha=$ intercept; $v_{i}=$ random effect of the $i$ th buffalo; $o_{j}=$ fixed effect of the $j$ th calving order; $c_{l}=$ fixed effect of the $l$ th season of calving; $(o c)_{k l}=$ fixed effect of interaction the $j$ th calving order and the $l$ th season of calving; ${ }_{j k l m}=$ residue.

\section{RESULTS AND DISCUSSION}

Descriptive statistics for milk yield, fat and protein percentage in the different farm were reported in Table 2.

Table 2 showed that the organic farm show minor milk production, in function of the limitations imposed by the EEC Regulation on nutrition livestock, show good qualitative characteristics of milk produced and minor content of S.C.C.t. These characteristics are correlated at good quality of feed in the organic farm.

Figure 1 showed the difference milk yield between farm at different season calving.

In function of feed disponibility, in different period of years, it appears evident that the buffalo cows that calving in the first six months of year, in the organic farm, were well feed, but, in traditional farm in the second period of the years, the animal have a disposition good mais silage that favourable the major milk production. The milk production is major, in traditional farm, in summer respect the winter (10.4 vs $6.34 \mathrm{~kg}$ of milk/day/head). In biological farm no significative difference between seasons were observed. Peak milk yield occurs, for both farm, at around the $6^{\text {th }}-7^{\text {th }}$ wk of lactation; the rate of decline following peak trend to increase with the age of animal.

Figure 2 showed the difference of fat content (\%) between farm at different season calving.

Table 2. Descriptive statistics for milk yield, fat, protein contents and S.C.C.t. between farms.

\begin{tabular}{|c|c|c|c|c|}
\hline & & Means & Std. Dev. & Std error \\
\hline \multirow[t]{2}{*}{ Milk yield (Kg/day/head) } & Organic farm & $7.77^{* *}$ & 3.35 & 0.08 \\
\hline & Conventional farm & $8.10^{* *}$ & 3.59 & 0.11 \\
\hline \multirow[t]{2}{*}{ Fat content (\%) } & Organic farm & $8.71^{* *}$ & 2.15 & 0.05 \\
\hline & Conventional farm & $7.98^{* *}$ & 1.93 & 0.06 \\
\hline \multirow[t]{2}{*}{ Protein content (\%) } & Organic farm & $4.71^{* *}$ & 0.42 & 0.01 \\
\hline & Conventional farm & $4.83^{* *}$ & 0.41 & 0.01 \\
\hline \multirow[t]{2}{*}{ Somatic cell count transformed } & Organic farm & $2.00^{* *}$ & 0.42 & 0.01 \\
\hline & Conventional farm & $2.07^{* *}$ & 0.50 & 0.02 \\
\hline
\end{tabular}

${ }^{* * *}$ Correlation is significant at the 0.01 level.

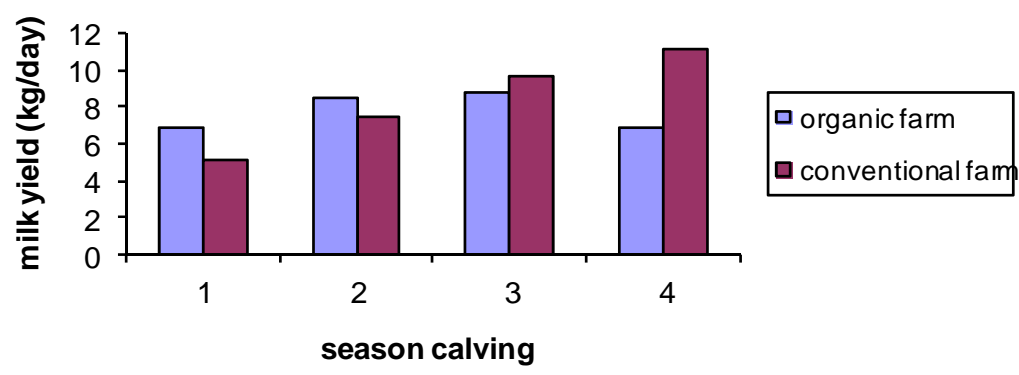

Figure 1. Different milk yield between organic and traditional farm at different season of calving.

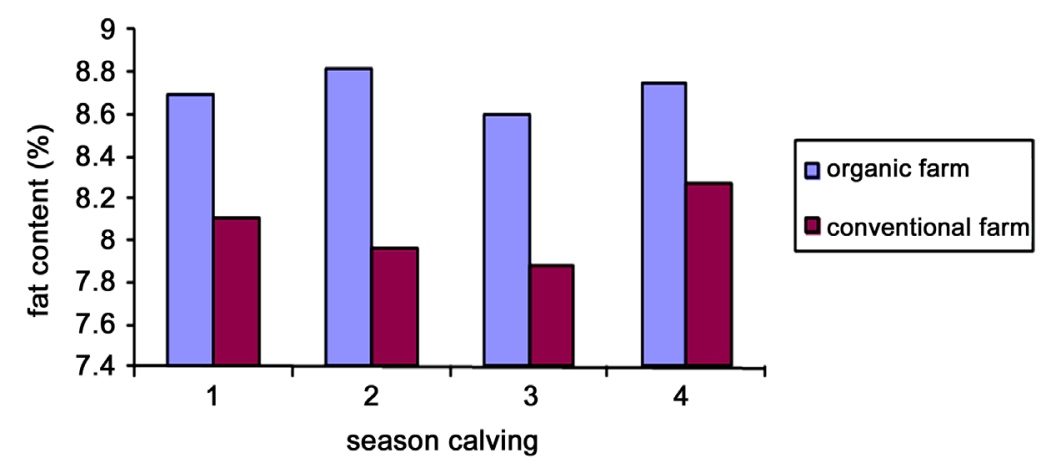

Figure 2. Different fat content (\%) between farm at different season calving. 
The organic farm shows a greater amount of fat in milk regardless of the season of calving compared with the conventional farm. This is justified of the better respect of animal welfare and quality of food to buffalo's cow administered also for the amount of forages administered.

No difference between the protein content of milk was found between the two companies considered.

Figure 3 showed the difference of S.C.C.t. between farm at different season calving.

An examination of Figure $\mathbf{3}$ is apparent that a the ration scheme at major concentrate content acting negatively on the mammary gland as resulted of the major S.C.C.t. con- tent in the milk in conventional than organic farm.

In Figure 4 we reported the milk yield trend between organic and traditional farm at different calving order.

Milk yield was mayor in the second month of lactation, but no for $2^{\text {nd }}$ and $5^{\text {th }}$ calving order, and then decreased from $6^{\text {th }}$ month of lactation for all parity and in both farm.

Daily milk yield increases with the age of animal until 5 to 6 yr of age and then decreases for buffaloes aged 7 yr and more according to reported by [3] in both farm. The effect of age on fat and protein content is negligible, whereas small differences among age can be found for protein percentage (Figure 5).

\section{SCCt content between farm at different season of calving}

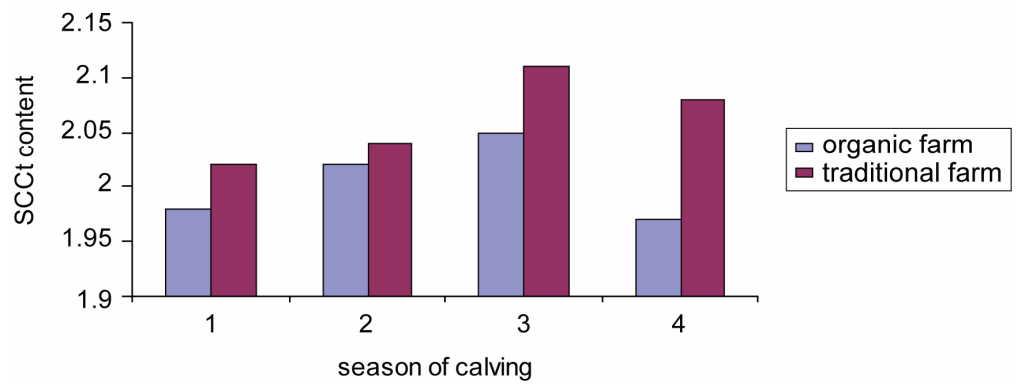

Figure 3. Different of S.C.C.t. between farm at different season calving.

Fat \% between farm at different season calving

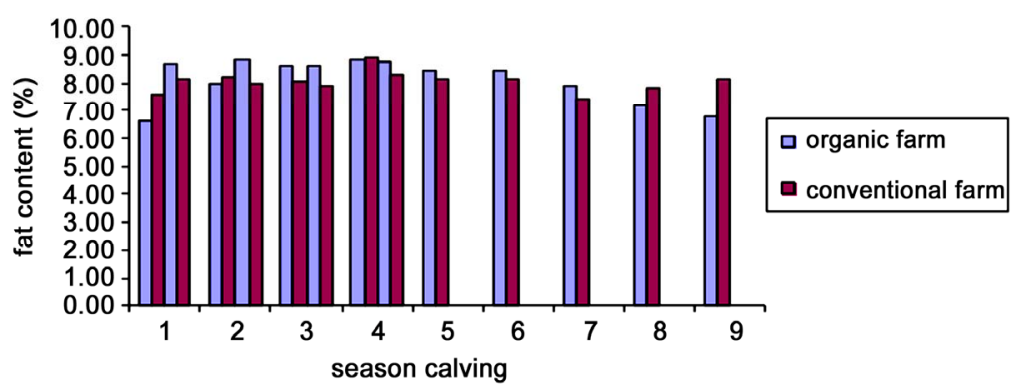

Figure 4. Milk yield trend between organic and traditional farm at different calving order.

Protein content (\%) between farm at different calving order

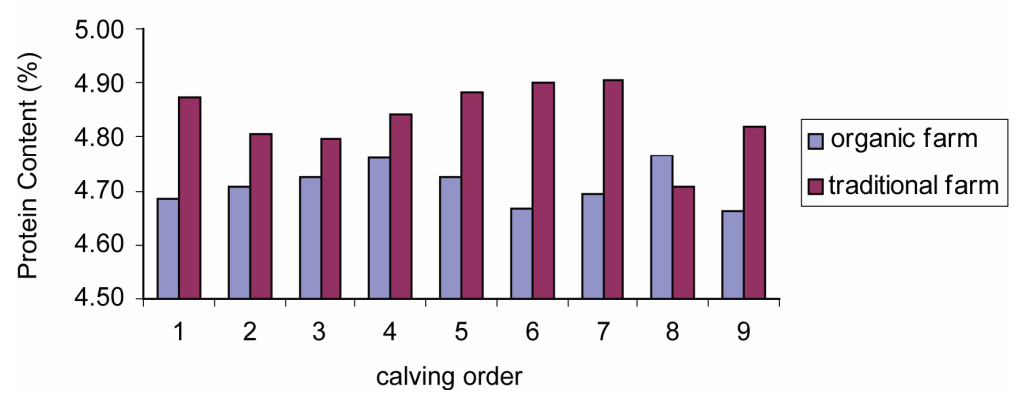

Figure 5. Protein content (\%) trend between organic and traditional farm at different calving order. 
Calving order affected milk yield only in the first three calving order with the lowest production levels in the first six months of the year for both farm; no effect could be observed on fat and protein contents.

Analysis of milk yield showed highly significant differences for fixed effect of season of calving $(\mathrm{P}<0.001)$ and also for calving order $(\mathrm{P}<0.001)$.

In the $7^{\text {th }}$ parity, the S.C.C.t. was lower than in all other parities. In the study conduced by [9] the S.C.C., in the first parity, was lower than in all other parities in all the months of lactation. [15] reported that the S.C.C.t. was high during the first phase of the lactation. In all of the parities S.C.C.t. decreased in the 3rd months of lactation and persisted constant in the others month of lactation.

[9] reported that S.C.C.t. decreased in the second month of lactation and increased thereafter up to the 9th month. In the work of [16] the S.C.C.t. decreased in the first 60 $\mathrm{d}$ of lactation and then increased.

The peaks of \%F were variable between calving orders: decreased starting to $4^{\text {th }}$ calving order with a trend that increases with advance of months of lactation.

Nothing variation exist for protein content in all parity and all calving order.

The all results were in agreement with literature reports.

\section{ACKNOWLEDGEMENTS}

Research supported by “Conoscenze Integrate per la Sostenibilità e l'Innovazione del made in Italy Agroalimentare” (CISIA-VaRiGeAV) -MIUR, Project “Caratterizzazione e valorizzazione delle risorse genetiche animali e vegetali della Campania e della Sardegna finalizzate allo sviluppo della filiera bufalina mediante approcci multidisciplinari ed innovativi”.

The authors are grateful to Giuseppe Grazioli and Francesco Marino for the technical assistance.

\section{REFERENCES}

[1] Associazione Italiana Allevatori-AIA (2006) Controlli della produttività del latte in Italia Roma Italia.

[2] Catillo, G., Moioli, B. and Napoletano, F. (2001) Estimation of genetic parameters of some productive and reproductive traits in Italian buffalo genetic evaluation with BLUP animal model. Asian-Australasian Journal Animal Science, 14, 747-753.

[3] Catillo, G., Macciotta, N.P.P., Carretta, A. and CappioBorlino, A. (2002) Effects of age and calving season on lactation curves of milk production traits in Italian water Buffaloes. Journal Dairy Science, 85, 1298-1306.
doi:10.3168/jds.S0022-0302(02)74194-5

[4] Jain, A. and Sadana, D.K. (2000) Sire evaluation using animal model and conventional methods in murrah buffaloes. Asian-Australasian Journal Animal Science, 13, 1196-1200.

[5] Jamrozik, J. and Schaeffer, L.R. (1997) Estimates of genetic parameters for a test day model with random regressions for yield traits of first lactation Holsteins. Journal Dairy Science, 80, 762-770. doi:10.3168/jds.S0022-0302(97)75996-4

[6] Swalve, H.H. (2003) Neue ansätze in der züchterischen bearbeitung funktionaler merkmale. Archiv Tierzucht, Dummerstorf, 46, 63-71.

[7] Coletta, A., Caso, C., Castrillo, M., Parlato, M., Zullo, A. and Zicarelli, L. (2007) Fit of the Wood function to milk yield data collected by different recording systems in Mediterranean Italian buffalo. Italian Journal Animal Science, 6, 503-505.

[8] Ptak, E. and Schaeffer, L.R. (1993) Use of test day yields for genetic evaluation of dairy sires and cows. Livestok Production Science, 34, 23-34. doi:10.1016/0301-6226(93)90033-E

[9] Ceròn-Muñoz, M., Tonhati, H., Duarte, J., Oliveira, J., Muñoz-Berrocal, M. and Jurado-Gamez, H. (2002) Factors affecting somatic cell counts and their relations with milk and milk constituent yield in buffaloes. Journal Dairy Science, 85, 2885-2889. doi:10.3168/jds.S0022-0302(02)74376-2

[10] Harmon, R.J. (1994) Physiology of mastitis and factors affecting somatic cell counts. Journal Dairy Science, 77, 2103-2112. doi:10.3168/jds.S0022-0302(94)77153-8

[11] Kitchen, B.J. (1981) Review of the progress of dairy science: Bovine mastitis: Milk compositional changes and related diagnostic tests. Journal Dairy Research, 48, 167188. doi:10.1017/S0022029900021580

[12] Ng-Kwai-Hang, K.F., Hayes, J.F., Moxley, J.E. and Monardes, H.G. (1982) Environmental influences on protein content and composition of bovine milk. Journal Dairy Science, 65, 1993-1998. doi:10.3168/jds.S0022-0302(82)82449-1

[13] Weaver, J.C. and Kroger, M. (1977) Protein, casein, and noncasein protein percentages in milk with high somatic cell counts. Journal Dairy Science, 60, 878-881. doi:10.3168/jds.S0022-0302(77)83957-X

[14] SPSS 12.0 Package Software (2003).

[15] Shook, G.E. and Schultz, M. (1994) Selection on somatic cell score to improve resistance to mastitis in the United States. Journal Dairy Science, 77, 648-658.

[16] Rodriguez-Zas, S.L., Gianola, D. and Shook, G.E. (2000) Evaluation of model for somatic cell score lactation patterns in Holsteins. Livestok Production Science, 67, 1930. doi:10.1016/S0301-6226(00)00193-7 